\title{
Pleuroxus aduncus (Jurine, 1820) and its geographic distribution, an addition to unraveling of "the Pleuroxus aduncus problem"
}

\author{
Pleuroxus aduncus (Jurine, 1820) и его географическое \\ распространение, к "проблеме Pleuroxus aduncus"
}

\author{
N.N. Smirnov \\ Н.Н. Смирнов
}

\begin{abstract}
A.N. Severtsov Institute of Ecology and Evolution, RAS, Leninskii prospect 33, Moscow, 119071 Russia.
Институт проблем экологии и эволюции им. А.Н. Северцова РАН, Ленинский проспект 33, Москва, 119071 Россия.
\end{abstract}

KEY WORDS: Pleuroxus aduncus, geographic distribution, South Africa., Pleuroxus aduncus f. lanceolatus f. nova.

КЛЮЧЕВЫЕ СЛОВА: Pleuroxus aduncus, географическое распространение, Южная Африка, Pleuroxus aduncus f. lanceolatus f. nova.

ABSTRACT. With consideration of recently added characters and materials the limits and geographic distribution of Pleuroxus aduncus are discussed. Presence of this species in Australasia and South Africa is confirmed. Pleuroxus aduncus f. lanceolatus f. nova is discerned from the middle Volga.

РЕЗЮМЕ. С учётом новых признаков и новых материалов обсуждаются пределы географического распространения Pleuroxus aduncus. Подтверждено присутствие этого вида в Австралазии и Южной Африке. В материале из Средней Волги выделена форма Pleuroxus aduncus f. lanceolatus f. nova.

In 1993 D. Frey (p. 149) commented on what he termed "the Pleuroxus aduncus problem" in connection with his investigation of Pleuroxus species from the subantarctic islands: "None of the taxa is closely enough related to $P$. aduncus to be considered a subspecies or variety of that taxon. $P$. aduncus does not occur on these subantarctic islands nor in the southernmost South America, Australia, or New Zealand. The investigation of the South African fauna has not yet been completed."

Fully accepting new and older species shown by Frey as only superficially similar to $P$. aduncus and even having added some new species of this group [Smirnov et al., 2006; Smirnov, 2007], still there is a question: what remains of $P$. aduncus, what are the actual limits of this species, supposed to be basically Palearctic?

Recently, many species of chydorids are redescribed and their taxonomic status is reconsidered, frequently on the basis of new characters, thus making previous determinations unreliable. Such is the case with Pleuroxus aduncus (Jurine, 1820). This chydorid is supposed to be a common, abundant, and widely distributed species. As new characters are now added, it was necessary to check if the available material conforms to the modern diagnosis and to check its actual distribution.

\section{Material}

The following examination is based of the materials in the author's collection and samples from South Africa loaned by K. Martens.

\section{History of the notion of Pleuroxus aduncus}

Recent detailed descriptions of "aduncus"-like forms and findings in cladoceran morphology much reduced the limits of the former Pleuroxus aduncus sensu lato [Frey, 1991, 1993; Smirnov et al., 2006].

Initially, Pleuroxus aduncus was suggested by Jurine in 1820 as Monoculus aduncus, collected from France (Châtelaine). On pages 152-153 of his extensive work he indicates the characters, of which none have any value to-day. The drawing (Plate 15, Fig. 8) demonstrates a Pleuroxus, but not anything more specific.

Jurine cites also Lynceus trigonellus Müller, 1785 as a probable synonym, but doubts the identity. The description supplied by Müller [1785: 74-75, Table 10, Figs. 5, 6] does not supply any characters which might delimit either of two names. There is no true evidence that what Jurine had seen was Pleuroxus aduncus. Thus, there are two possibilities - either it was really so, or it was $P$. trigonellus (Müller, 1785) (also not defined by its author, by later standards).

The true history of this species, though currently listed as Pleuroxus aduncus (Jurine, 1820), begins with Lilljeborg [1901: 541-545, Pl. 75, Figs. 11-17]. Lilljeborg was the first to note that the males of $P$. aduncus 


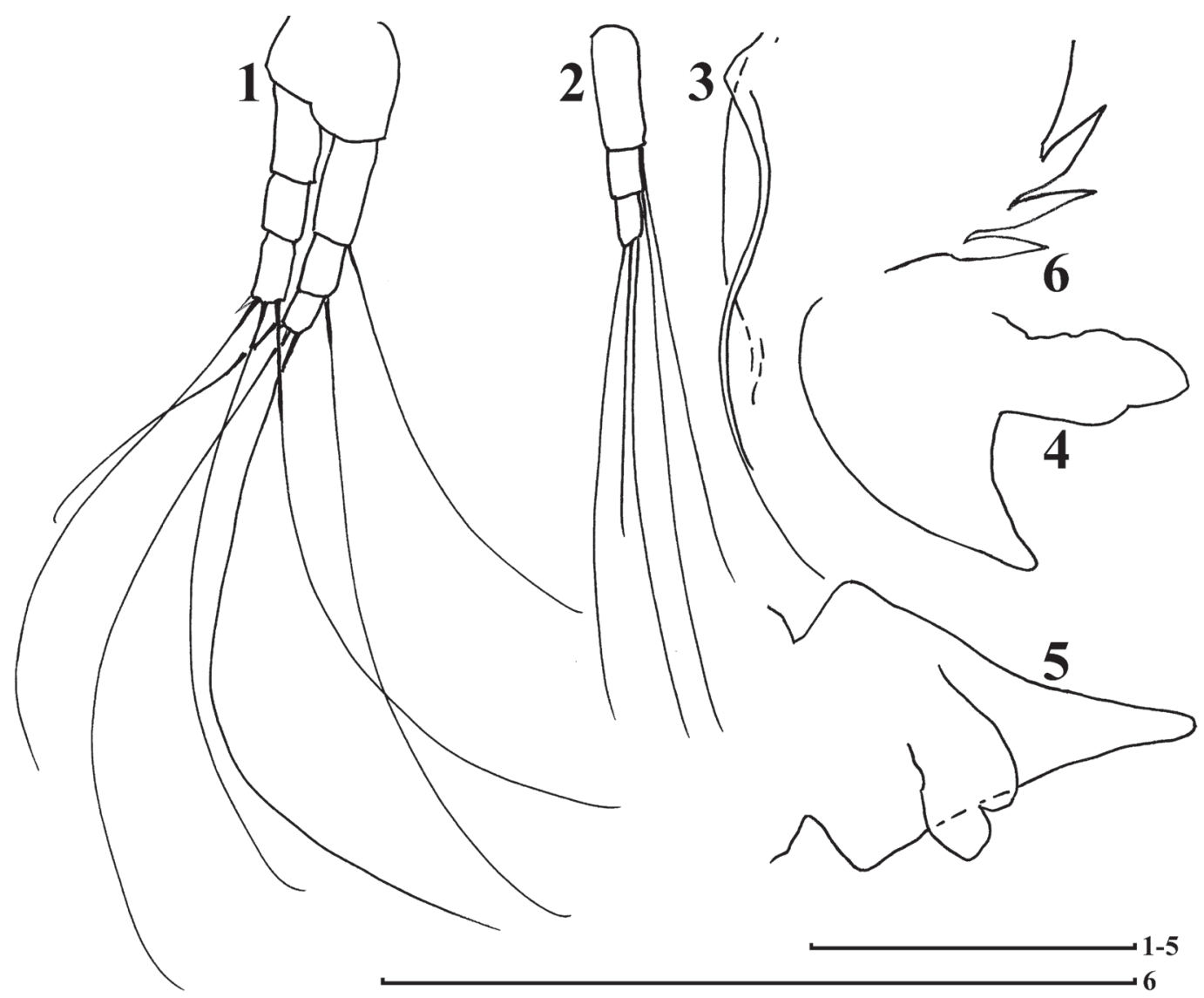

Fig. 1-6. Pleuroxus aduncus, South Africa (1-5): 1 - antenna, left, from inside; 2 - antennal endopodite; 3 - accessory anterior flange (AAF), left valve; 4 - labral lamella, left-side view; 5 - labral lamella, ventral view; 6 - denticles at the ventro-posterior angle of valve. 1 - RSA/93/128, NNS-2002-158; 2, 4, 5 - RSA/89/057, NNS-2002-195; 3 - RSA/94/029, NNS-2002-094; 6 - Pleuroxus aduncus f. lanceolatus f. nova, Kuybyshev Reservoir (the Middle Volga, 17 June 1961, NNS-1999-053). Scale bar: 1-5 - $0.1 \mathrm{~mm}, 6$ $0.1 \mathrm{~mm}$.

Рис. 1-6. Pleuroxus aduncus, Южная Африка (1-5): 1 - антенна, левая, с внутренней стороны; 2 - эндоподит антенны; 3 добавочный передний фланец (AAF), левая створка; 4 - пластинка лабрума, вид слева; 5 - пластинка лабрума, вид снизу; 6 зубчики заднее-нижнего угла створки. 1 - RSA/93/128, NNS-2002-158; 2, 4, 5 - RSA/89/057, NNS-2002-195; 3 - RSA/94/029, NNS-2002-094; 6 - Pleuroxus aduncus f. lanceolatus f. nova, Куйбышевское водохранилище (Средняя Волга), 17 июня 1961, NNS1999-053). Масштаб: 1-5 - 0,1 мм, $6-0,1$ мм.

and $P$. trigonellus are clearly different while the females differ rather little.

Of the characters important within the present context, the following ones were found by Lilljeborg in females from Sweden: 1-3 small denticles at the ventro-posterior angle of valve (in his Fig. 11 the denticles are short and triangular), valve with lines and traces of irregular reticulation, ventral margin of valve finely serrated, antenna with eight setae, the seta on the basal segment of endopodite is smaller than other setae (but nevertheless long), postabdomen with a double row of 10-12 small anal teeth, there are groups of small lateral setae. No details on thoracic limbs were described.

Lilljeborg noted the following differential characters in males of $P$. aduncus: the ventro-posterior angle of the valve usually with three denticles, postabdomen gradually narrowing distally, anal margin slightly concave, postanal margin near postanal angle slightly con- cave, anal teeth as minute setae, the postabdominal claw with one small basal spine, vasa differentia open at the base of claws, ventrally of them.

Harding [1955] and Smirnov [1971] combined all similar forms into one species and assumed its wide distribution. Later, this viewpoint had to be abandoned.

Smirnov [1971], on the material from the Upper Volga, gave a detailed representation of thoracic limb I as having Inner Distal Lobe (IDL) with tree setae, of which one is short and a longer one is much stronger than the others. Gnathobasic filter setae on limbs IV and $\mathrm{V}$ are 6 and 4 . For the first time the head shield of $P$. aduncus was shown with head pores at about two interpore distances from the posterior end of the head shield.

Controversial and confusing reports of $P$. aduncus, especially those from extraeuropean localities, induced Frey [1991] to make a complete redescription of fe- 
males and males of $P$. aduncus from Denmark. Of the complete set of characters, the following ones turned out to be crucial: of antennal terminal setae on the endopodite one seta is much shorter than other two, gnathobasic filtering setae on limbs II-V are 8-8-6-4. In this material North Europe the denticles at the ventro-posterior angle of valve were short, triangular. Frey also counted the number of ventral setae on valve as 79-89 and indicated presence of a basal peg in the antennule. The latter was thought typical for P. aduncus sensu lato by Harding [1961].

The difference in length of terminal setae was so definite that Frey did not apply any statistical methods to qualify it. However, Frey [1991, 1993] compared their relative length in every new and redescribed species. It turned out that the antennal terminal setae in different species are either (1) equal in length, or (2) moderately different $(P$. foveatus Frey, 1991, $P$. helvenacus Frey, 1991, P. wittsteini Frey, 1993, P. scopuliferus (Ekman, 1900), Plurispina multituberculata Frey, 1991, Archepleuroxus baylyi Smirnov et Timms, 1983), or (3) very different (P. aduncus, P. hastirostris Sars, 1903, P. macquoriensis Frey, 1993, $P$. paraplesius Frey, 1993, P. varidentatus Frey, 1993, Plurispina chauliodes Frey, 1991).

Frey doubted presence of $P$. aduncus in the southern hemisphere.

The previous occurrences, especially those at the periphery of the area, should be checked against the above characters. In none of them, the antennal setae were previously characterized. The present attempt is mainly application of the new character, different length of terminal antennal setae, introduced by Frey, to identification of aduncus-like specimens. In what was decided to be a true "aduncus" one of the terminal setae was always clearly shorter than others, as indicated by Frey. No uncertain situations occurred.

\section{Terminal antennal setae - a neglected character}

Sars [1861 (1993)] drew the antenna of Cladocera with setae in their full length and demonstrated that in chydorids sometimes they characteristically differ in length (in Disparalona rostrata (Koch, 1841), Graptoleberis testudinaria (Fischer, 1851), Rhynchotalona falcata (Sars, 1861))

Later, Sars [1901] either did not mention the structure of the antenna, or just noted that "The antennae exhibit the usual structure" [Sars, 1888: 49], or when obviously different he described the antenna in sufficient detail [Sars, 1894]. While Sars [1861, Pl. 91, Fig. 13] clearly indicated that in $P$. trigonellus the terminal antennal setae on both antennal branches are of equal length, the same situation in $P$. uncinatus remained unknown and neglected.

The majority of the subsequent authors did not draw antennal setae, probably as inconveniently long, assuming that they do not supply any useful characters. Sinev found that relative length of termimal (apical) antennal setae is important in systematics of Acroperus.

\section{Variation of structures}

In addition to the changing set of diagnostic features and increasingly higher detail of species discrimination, one more source of difficulties defining $P$. aduncus is morphological variation. The postabdomen characteristic of $P$. aduncus may vary, within the limits characteristic of this species, in form, size, and distribution of anal teeth. The number of marginal setae on valve varies within a certain range (according to Frey [1991], 79-89 in topotypic material). Labral lamella is variable (as shown by Frey, 1991, Figs. 7-14) and may be sometimes distorted in shape (abnormal). Length of terminal setae of the endopod may vary in relation to the ramus length.

The denticles at the ventro-posterior angle of valve vary in size, form, and number (from 3 to 0 ). Generally, they are small, short-triangular, and posteriorly directed. In many females from the Kuybyshev Reservoir (the Middle Volga, July 17, 1961, leg. N.N. Smirnov, NNS-1999-053) these denticles are lanceolate, slightly constricted at the base, either single or grouped by $2-3$, ca $0.01 \mathrm{~mm}$ long (Fig. 6). Such specimens deserve the name Pleuroxus aduncus f. volgensis f. nova. Other characters of these specimens are as in the typical form, gnathobasic setae of thoracic limbs II-V 8-8-6-4. Some specimens from Lake Svyatoe (Moscow) also have small lanceolate denticles of valve [Smirnov, 1996, Fig. 161].

Generally, there is a "bush" of aduncus-like species [Smirnov et al., 2006], each of these species having just slightly differing morphological characters.

\section{Specimens from periphery of the area}

\section{Asiatic}

Terminal setae of the antennal endopod are checked in 'aduncus'-like specimens from distant areas, probably from the periphery of its area. Two long setae and one much shorter seta on the antennal endopod are found at the background of similarity of external characters to $P$. aduncus in the following specimens:

AZERBAIJAN, Lenkoran, Lake Olkhovskoe, December 9, 1951, NNS-1999-188;

UZBEKISTAN, Fergana, a pond in Margelan Sai, August 14, 1950, NNS-1999-089;

UZBEKISTAN, SW Kyzyl-Kum 45 km of Nuraty, October 20, 1962, NNS-1999-090;

IRAQ, the Euphrates at Chibayish, November 18, 1974, NNS1999-091;

IRAQ, Tharthar man-made lake, below dam, November 11, 1974, NNS-1999-092.

\section{Extraeurasiatic} 093.

MAROCCO, Barrage Ksarfes-Souk, July 28, 1971, NNS-1999-

AUSTRALIA, NEW SOUTH WALES -

Kiah Lake via Berridale, May 12, 1975, NNS-1999-070; Isand Lake, May 12, 1975, NNS-1999-066; 

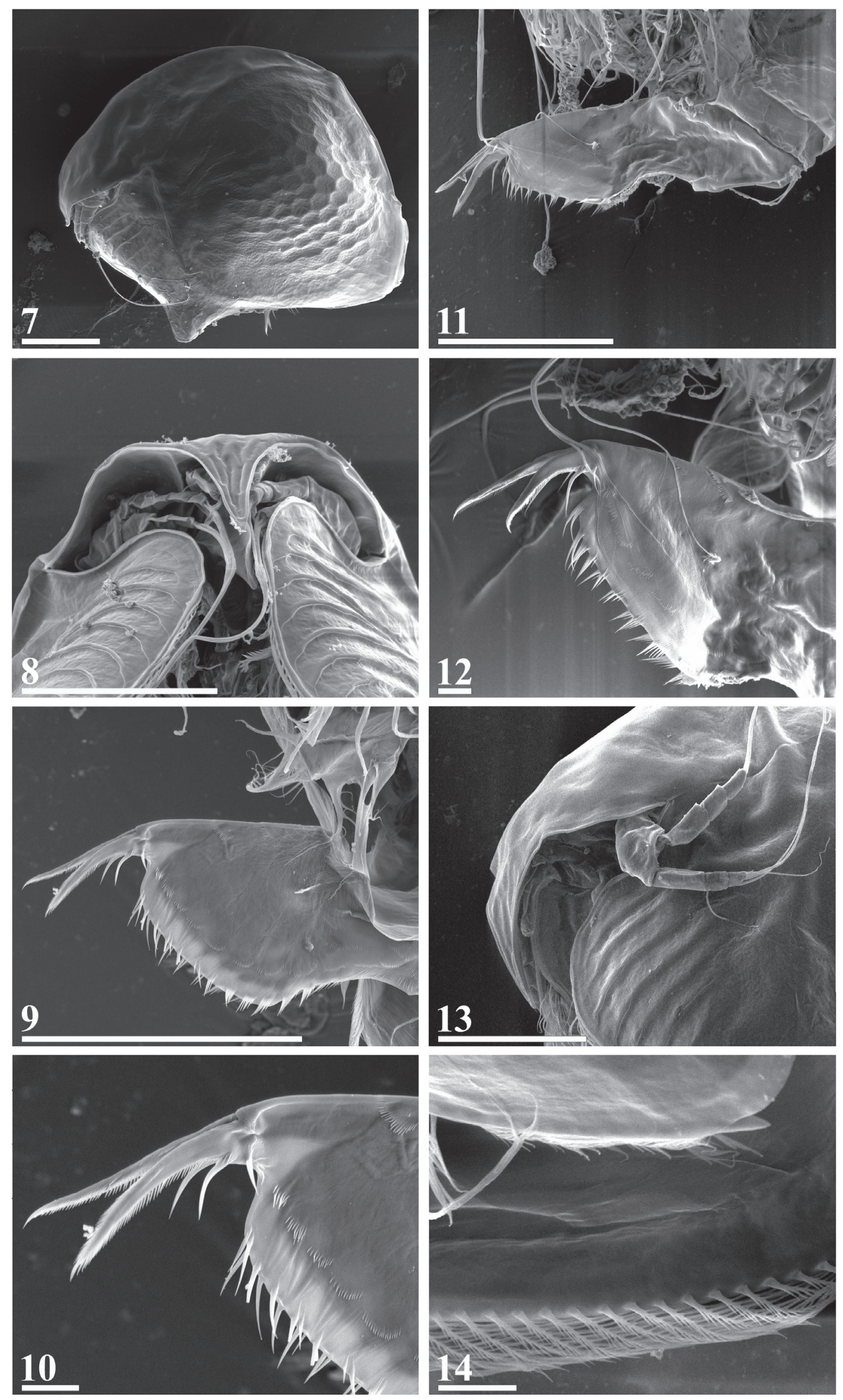
Lake E of Carrol's Lake, May 13, 1975, NNS-1999-073; Myall Lake at Shelley pt., September 9, 1973, NNS-1999-094; Hexham Swamp via Newcastle, July 3, 1977, NNS-1999-094; Black Lake via Bombala, April 14, 1975, NNS-1999-098; Lake Surprise, NNS-1999-101;

AUSTRALIA, SOUTHERN AUSTRALIA -

Sewage Lagoon, August 30, 1978; NNS-1999-096; AUSTRALIA, WESTERN AUSTRALIA -

Loc. 93 (Bayly) July 3, 1977, NNS.1999. 074;

TASMANIA, Weedding's Lagoon, May 9, NNS-1999-068;

NEW ZEALAND, Farm Dam, Silverdale, August 1964, NNS1999-095.

\section{South Africa as a special case}

South Africa makes a special case, as it harbors both local species and several Palearctic species (indistinguishable from the European ones). Inter alia, detailed examination of thoracic limbs is necessary.

Therefore a closer check was made in the following nine samples on specimens that appeared to be $P$. aduncus. Not less than two specimens from each sample were examined for the size of terminal antennal setae, number of gnathobasic setae on limbs II-V, number of ventral setae on valve, and the form of denticles at the ventro-posterior angle of valve.

RSA/94/022, NNS-2002-089. KwaZulu - Natal, Jagersrust, Kilburn dam, Spilling pool, October 21, 1994. 1220 m asl, conductivity $186 \mu \mathrm{S} / \mathrm{cm}, 23.5^{\circ} \mathrm{C}, \mathrm{pH} 8.1$;

RSA/94/029, NNS-2002-094. KwaZulu - Natal, Erfdeel Farm dam, October 21, 1994, conductivity $990 \mu \mathrm{S} / \mathrm{cm}, 20^{\circ} \mathrm{C}$, pH 9.4;

RSA/89/031, NNS-20020188. Eastern cape, Lesser Karoo, Dam 5, road Bedfors-Cradock, km. 41, December 8, 1989, 153.9 iS/cm, $27.4^{\circ} \mathrm{C}, \mathrm{pH} 6.8$;

RSA/93/045, NNS-2002-139. Eastern Cape, Rhodes, Carlisle's Hoek Plateau River, April 1, 1993, $3000 \mathrm{~m}$ asl, $75 \mu \mathrm{S} / \mathrm{cm}, 18.3^{\circ} \mathrm{C}$, $\mathrm{pH} \mathrm{8}$;

RSA/89/047, NNS-2002-192. Eastern Cape, River Pool 1, road Grahamstown-Bedford, km 11, December 12, 1989, $2430 \mu \mathrm{S} / \mathrm{cm}$, $24.4^{\circ} \mathrm{C}, \mathrm{pH} 7.9$;

RSA/89/048, NNS-2002-193. Eastern Cape, Dam 2, Grahamstown-Bedford, $\mathrm{km} \mathrm{11.8,} \mathrm{December} \mathrm{12,} 1989,912 \mathrm{~m}$ asl, $25.9^{\circ} \mathrm{C}$, $\mathrm{pH} 8.4$;

RSA/89/057, NNS-2002-195. Eastern Cape, Dam 10, road Grahamstown-Bedford, km 69, December 12, 1989, conductivity $21 \mu \mathrm{S} / \mathrm{cm}, 32.6^{\circ} \mathrm{C}, \mathrm{pH} 7.4$

RSA/93/126, NNS-2002-157, Freestate, Pan 4, road Southpan-Dealesville, April 23, 1993, $1418 \mathrm{~m}$ asl, $18^{\circ} \mathrm{C}, \mathrm{pH} 8.8$;

RSA/93/128, NNS-2002-158. Freestate, Bloemforntein, Griffith's farm. $2^{\text {nd }}$ dam, April $24,1993,902 \mathrm{~m}$ asl, $17.5^{\circ} \mathrm{C}, \mathrm{pH} 9.1$.

In all specimens from the above nine samples the following characters typical of true $P$. aduncus were found (Figs. 1-5, 7-14): terminal setae of antennal endopod - one short, two long, gnathobasic filter setae of limbs II-V 8-8-6-4, denticles at ventro-posterior angle of valve short, triangular, 1/1, 2/1 (left/right valve), valve with about $70-83$ ventral plumose setae, postabdomen with characteristic "underdeveloped" anal teeth, general habit typical of $P$. aduncus.

In the course of preliminary examination of this material it was erroneously concluded that some speci- mens externally similar to $P$. aduncus possess the terminal antennal setae are all long [Smirnov, 2008] and thus they might be different from the typical $P$. aduncus. Detailed examination of the above samples revealed that this is not so.

Reports on P. aduncus from Central, West, and North Africa do not contain sufficient detail (on the antennal setae including) to estimate its precise distribution in Africa [Gauthier, 1928; Rey, Saint-Jean, 1969; Kořínek, 1984; Chiambeng, Dumont, 2004]. No material is available in the author's collection too.

\section{Actual limits of the geographic range of $P$.} aduncus

Europe being the main part of the area of $P$. aduncus, the area extends to Asia. P. aduncus seems to be present in samples collected in East Siberia. the lower reaches of the Amur, vicinities of Vladivostok, Kamchatka, and Sakhalin by N.M. Korovchinsky, A.A. Kotov, and E.I. Bekker.

However, the southern limits of the area are still not known. Reliable southernmost occurrences are confined to India [George Michael, Sharma, 1988], Uzbekistan, Azerbaijan, and Iraq. The Cape Province is now added as an isolated area, within $28^{\circ} 35^{\prime}-$ $34^{\circ} \mathrm{S}, 18^{\circ}-29^{\circ} \mathrm{E}$.

From Australasia, specimens externally similar to $P$. aduncus are collected in many localities of New South Wales, Victoria, and in Tasmania. The Australasian specimens listed above all had two long setae and one much shorter seta on the antennal endopod. Thorough investigation, with consideration of the complex of morphological characters, may further confirm if the true $P$. aduncus is actually present in Australia. Possibility of it presence in Australia is supported by records of some Eurasian species as, e.g., Alona intermedia (Sars, 1861) and Pleuroxus globosus (Baird, 1843), both reported from Australia and South Africa.

Specimens from Australasia, South America, and North America should be further studied in detail.

ACKNOWLEDGMENTS. SEM photographs are made and provided by A.A. Kotov. South African samples are loaned by K. Martens. The present study is supported in part by the Russian Foundation for Basic Research (grant No. 12-04-00207-a) and by the Program "Living Nature: Recent State and Development Problems".

\section{References}

Chiambeng G.Y., Dumont H.J. 2004. The genus Pleuroxus Baird, 1843 (Crustacea: Anomopoda: Chydoridae) in Cameroon, Cen-

Fig. 7-14. Pleuroxus aduncus, South Africa: 7 - right-side view; 8 - anterior part, ventral view; 9, 11, 12 - postabdomen; 10 claw; 13 - anterior part with antenna; 14 - Ventro-posterior angle and a part of ventral margin. 7, 11-14 - RSA/94/029, NNS-2002094; 8, 9, 10 - RSA/93/128, NNS-2002-158. Scale bar: 7-9, 11, $13-0.1 \mathrm{~mm}, 12,14-0.01 \mathrm{~mm}$.

Рис. 7-14. Pleuroxus aduncus, Южная Африка: 7 - вид справа; 8 - передняя часть, вид снизу; 9, 11, 12 - постабдомен; 10 коготок. 13 - передняя часть с антенной; 14 - задне-нижний угол и часть вентрального края. 7, 11-14 - RSA/94/029, NNS2002-094; 8-10 — RSA/93/128, NNS-2002-158. Масштаб: 7-9, 11, 13 - 0,1 мм, 10, 12, $14-0,01$ мм. 
tral West Africa // Ann. Limnol. - International journal of limnology. Vol.40. No.3. P.21-229.

Frey D.G. 1991. The species of Pleuroxus and of three related genera (Anomopoda, Chydoridae) in Southern Australia and New Zealand // Records of the Australian Museum. Vol.43. P.291-372.

Frey D.G. 1993. Species of Pleuroxus (Anomopoda, Chydoridae) from the subarctic islands and southernmost South America: a partial unraveling of the Pleuroxus aduncus problem // Hydrobiologia. Vol. 262. P.145-188.

Gauthier H. 1928. Recherches sur la faune des eaux continentals de l'Algérie et de la Tunisie. Alger: Minerva. $420 \mathrm{p}$.

George Michael R., Sharma B.K. 1988. Fauna of India. Indian Cladocera (Crustacea: Branchiopoda: Cladocera). Calcutta: Zoological Survey of India. $262 \mathrm{p}$.

Harding J.P. 1955. The Percy Sladen Trust Expedition to Lake Titicaca in 1937: Crustacea: Cladocera // Transactions of the Linnean Society of London. Vol.1. No.3. P.329-354.

Harding J.P. 1961. Some South African Cladocera collected by Dr A.D. Harrison // Annals of the South African Museum. Vol.46. Pt.3. P.35-47.

Jurine L. 1820. Histoire des monocles, qui se trouvent aux environs de Genève. Paris: Paschoud. 260 p.

Kořínek V. 1984. Cladocera // Hydrobiological Survey of the Lake Bangwelulu Luapula River Basin. Vol.13. No.2. P.1-117.

Lilljeborg W. 1901. Cladocera Sueciae // Nova acta regiae societatis scientiarum upsaliensis. Seriei tertiae. Vol.19. P.1-701.

Rey J., Saint-Jean L. 1969. Les cladocères (Crustacés Branchiopodes) du Tchad (Deuxième note) // Cah. ORSTOM. Ser. Hydrobiologie. Vol.3. No.3/4. P.21-42.

Sars G.O. (1861) 1993. On the freshwater crustaceans occurring in the vicinity of Christiania. University of Bergen. P.1-197.
Sars G.O. 1888. Additional notes on Australian Cladocera raised from dried mud // Forhandlinger i Videnskabs-Selskabet i Christianias. P.1-74.

Sars G.O. 1894. Contributions to the knowledge of the freshwater Entomostraca of New Zealand as shown by artificial hatching from dried mud // Videnskabet-Selskabet skrifter. I. Mathem.naturv. Klasse. Vol.5. P.1-62.

Sars G.O. 1901. Contributions to the knowledge of the Entomostraca of South America, as shown by Artificial hatching from the dried material // Ark. Math. Naturv. Vol.23. P.1-102.

Smirnov N.N. 1971. [Chydoridae of the World fauna] // Fauna SSSR. Rakoobraznye. Vol.1. No.2. 531 p. Leningrad: Nauka. [in Russian].

Smirnov N.N. 1996. Cladocera: the Chydorinae and Sayciinae (Chydoridae) of the World // Guides to the identification of the microinvertebrates of the continental waters of the World. Amsterdam: SPB. Vol.11. $197 \mathrm{p}$

Smirnov N.N. 2007. Pleuroxus-like chydorids (Crustacea: Anomopoda) from South Africa, with the description of Dumontiellus africanus gen. n., sp. n. // Hydrobiologia. Vol.575. P.433-439.

Smirnov N.N. 2008. Check-list of the South-African Cladocera (Crustacea: Branchiopoda) // Zootaxa. Vol.1788. P.47-56.

Smirnov N.N., Kotov A.A., Coronel J.S. 2006. Partial revision of the aduncus-like species of Pleuroxus Baird, 1843 (Chydoridae, Cladocera) from the southern hemisphere with comments on subgeneric differentiation within the genus // Journal of Natural History. Vol.40. P.1617-1639.

Smirnov N.N., Timms B.V. 1983. A revision of the Australian Cladocera (Crustacea) // Records of the Australian Museum. Sydney. Suppl.1. P.1-132.

Responsible editor K.G. Mikhailov 